\title{
Detection of mammary adenocarcinoma metastases in a cat through ${ }^{99 m}$ Tc-thymine scintigraphy
}

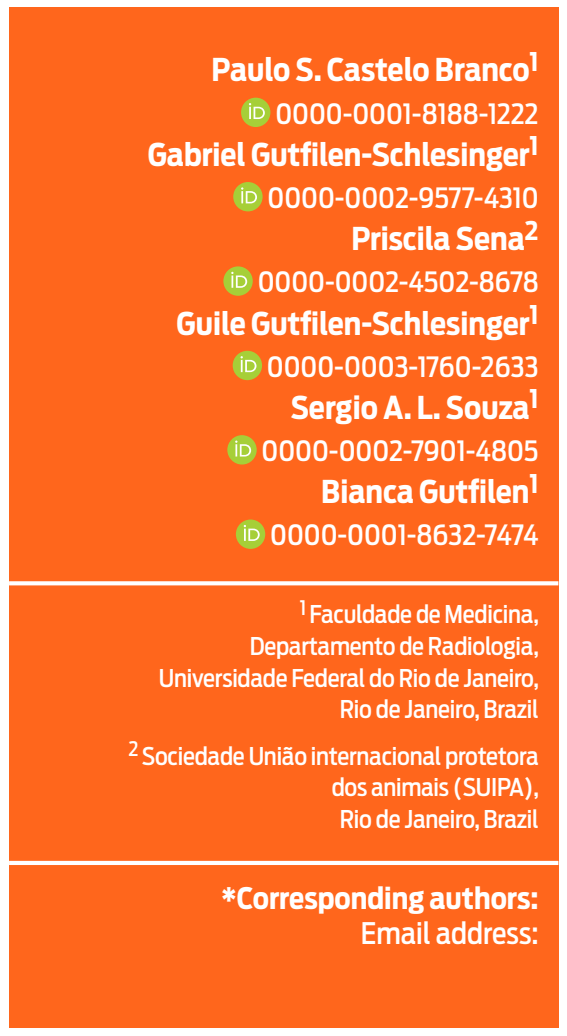

Accepted: $2020-05-25$ Published: 2020-06-30

Additional information and declarations can be found on page 7

@C) Copyright 2020 Paulo S. Castelo Branco et al. open access $\boldsymbol{\odot}$

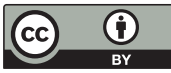

Distributed under Creative Commons CC-BY 4.0

\begin{abstract}
Mammary adenocarcinomas with metastases are more common in dogs than in cats. Their incidence is 1 in every 4,000 cats. In routine veterinary practice, laboratory exams for diagnosis of these neoplasms are nonspecific and scarcely used. Even though invasive procedure, biopsy, and histopathological findings are the gold standards that define the clinical approach, the clinical evaluation, and image assessment lead the way to the proper treatment, especially when surgical intervention is a possibility. This study describes the clinical signs, histopathological aspects, radiological and scintigraphic findings of a cat with mammary adenocarcinoma and metastases evaluated one hour

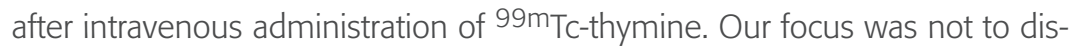
cuss the pathological aspects of the disease but the Nuclear Medicine role in metastases detection. Metastases, when lesser than $4 \mathrm{~mm}$, could go unnoticed by radiological exams, whereas scintigraphy may detect them. Using 99mTc-thymine scintigraphy, we successfully detected unsuspected metastases in the lungs, liver, and right kidney. Early diagnosis is the key to a better rate of survival due to the given treatment and prognostic. Hence, we strongly recommend the use of $99 \mathrm{~m}$ Tc-thymine scintigraphy as a complementary tool for breast cancer diagnosis in veterinary care.
\end{abstract}

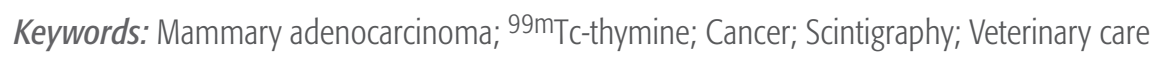

\section{Cite this as:}

Castelo Branco PS, Schlesinger GG, Sena P, Schlesinger GG, Souza SAL, Gutfilen B. Detection of mammary adenocarcinoma metastases in a cat through ${ }^{99 \mathrm{mT}} \mathrm{T}$-thymine scintigraphy. Veterinaria México OA. 2020;7(2). doi:10.22201/fmvz.24486760e.2020.2.718. 


\section{Introduction}

Mammary gland tumor is the third most common neoplasia in cats. It is mostly found in elderly felines ranging from 10 to 14 years old. Its incidence could be heightened by estrogen therapy, pseudocyesis, obesity, and a high-fat diet at a young age. ${ }^{1-5}$ This tumor can be affecting one or several glands in the mammary chain, ulcerated or not and can produce a discharge that could be mistaken as lactation. The diameter of the tumor is an important prognostic factor: cats with small tumors have a higher survival rate after their excision. Accurate metastasis detection can also aid to predict the best way to treat patients. ${ }^{6}$ The most frequent type of mammary tumor in cats is adenocarcinoma. It has a fast growth rate and can spread out to regional lymph nodes and other locations such as pleura, liver, and lungs. ${ }^{7-10}$ Primary pulmonary neoplasia patients may present different clinical features such as chronic cough, weight loss, exercise intolerance, tachypnea and/or dyspnea, that could be misinterpreted for heart diseases or other. ${ }^{11-13}$

Early metastases diagnosis can play a crucial role in improving patients' prognosis. Even though there are tissues and organs more likely to harbor metastases, it remains a challenge to locate them with ultrasonography or conventional radiology techniques. In contrast, the Nuclear Medicine approach allows a whole-body scan to locate and detect different types of tumor lesions. Thus, nuclear medicine is a promising tool for veterinary oncology. ${ }^{14-16}$ Here we evaluated a cat with mammary cancer carrying out scintigraphy with ${ }^{99 m}$ Technetium-thymine ( $\left.99 \mathrm{~m} \mathrm{Tc}-\mathrm{THY}\right)$, a radionucleotide developed by our research group, and that has been successfully used for the detection of breast tumors in women. ${ }^{17-19}$

For an efficient labelling method of tumors, radiopharmaceuticals should highlight the investigated tissue/pathology. Since neoplasms have an intense mitotic activity, they readily incorporate the radioactive material, enabling tumor diagnosis and staging. ${ }^{20-22}$ We have shown that thymine, a nitrogen base of the DNA structure, is highly integrated by the neoplastic cells in tumors such as bronchogenic carcinoma, lymphoma, and breast carcinoma in women. ${ }^{17,18}$ In 2001, Gutfilen et al. found that $99 \mathrm{mTc}-\mathrm{THY}$ is superior to $99 \mathrm{~m} \mathrm{Tc}-\mathrm{MIBI}$ on sensitivity $(95.83 \% \mathrm{vs}$. $95.65 \%)$, specificity (94.73\% vs. $71.42 \%)$, accuracy (97.61\% vs. $86.48 \%$ ) and positive predictive value ( $95.83 \%$ vs. $84.61 \%$ ) on mammalian cancer detection. ${ }^{18}$

This study aimed to determine the contribution of $99 \mathrm{mTC}-\mathrm{THY}$ scintigraphy in the evaluation and detection of mammary adenocarcinoma metastases in a cat.

\section{Material and methods Patient and clinical aspects}

A shorthaired Brazilian nine-year-old domestic queen, weighing approximately $4 \mathrm{~kg}$, presented with masses spread throughout all four mammary gland-pairs. Other clinical signs as anorexia, apathy, difficult breathing, and progressive weight loss were present. Urinalysis, blood exams and conventional radiographic examination results were normal. Two months later, the patient underwent $99 \mathrm{mTc}$ THY scintigraphy for further metastatic investigation. Few days after performing the scintigraphy, the patient died. We proceeded the investigation with necropsy after the owner's written consent. Unfortunately, the ultrasound examination was not performed at the time the patient came to our hospital. 


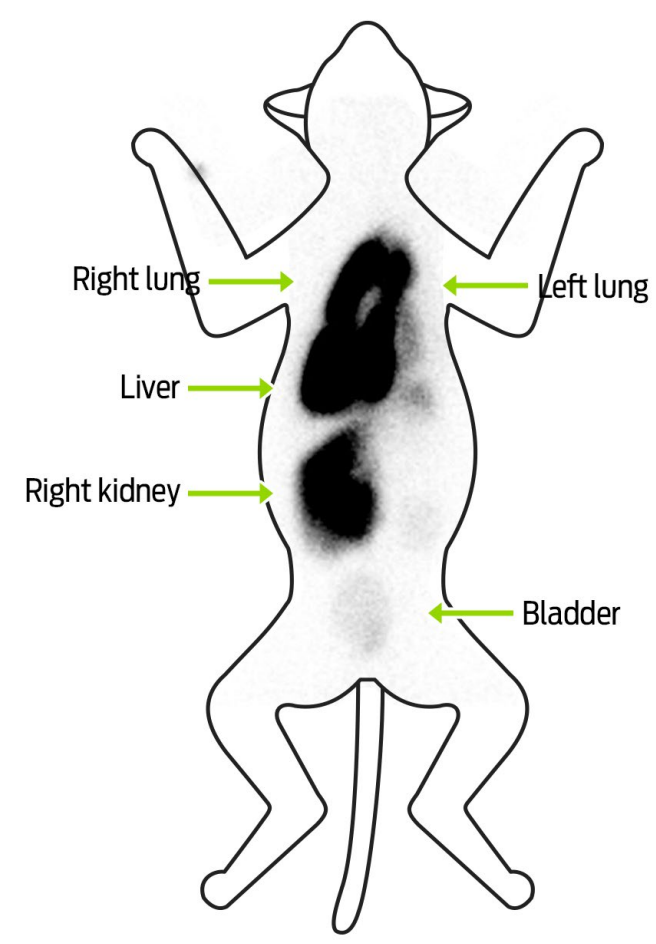

Figure 1. 99mTc-THY scintigraphy ventrodorsal images showed increased uptake areas corresponding to the liver, lungs, and unexpectedly, to the right kidney.

\section{Sedation and scintigraphy}

An anesthetic protocol, including ketamin 10\% (15 mg/kg) combined with xylazine $2 \%(2 \mathrm{mg} / \mathrm{kg})$, was administered intramuscularly prior to the scintigraphy. In order to perform the scintigraphy procedure, $0.9 \mathrm{mCi}(0.2 \mathrm{~mL})$ of $99 \mathrm{mTc}-\mathrm{THY}$ were injected into the cephalic vein. One hour after the radionuclide injection, the patient was placed in dorsal decubitus for image acquisition. Ventral and dorsal planar images of whole-body were acquired in a General Electric Millennium gamma-camera (General Electric Healthcare, Chicago, IL, USA), with a low energy collimator.

\section{Necropsy and histopathological analyses}

Tissue from lungs, heart, spleen, liver, breast, right kidney, and intercostal mus-

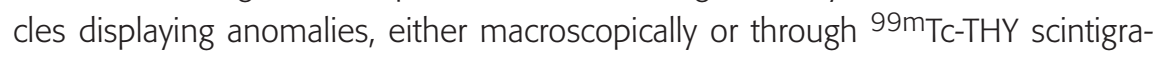
phy, were sampled and stained with hematoxylin and eosin for further histological analysis.

\section{Results and discussion}

Two months before the scintigraphy procedure, thoracic radiography was performed (ventrodorsal and latero-lateral planes), and no metastatic processes were

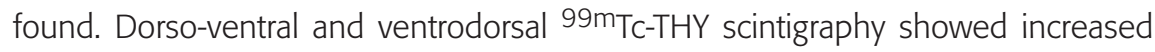
focal uptake in the liver and lungs, and unexpectedly a very high uptake of radionucleotide was observed in the right kidney. Further, wide-spread nodular alterations were found across the lungs, liver and intercostal muscles at necropsy (Figure 1). 
Histopathological studies revealed a simple type of invasive tubular mammary adenocarcinoma spreading into the dermis with extensive tumor necrosis, and peripheral lymphocytic infiltrate (Figure 2A). Tubular adenocarcinoma metastases of probable mammary origin with tumor necrosis and moderated mitotic activity were found in the lungs, liver, right kidney, and intercostal muscles (Figures 2B-D).

Over $80 \%$ of cats' mammary gland masses are malignant, ${ }^{23}$ and the most common are adenocarcinomas. ${ }^{8}$ Squamous cell carcinomas, melanomas, hemangiosarcomas, and mammary carcinomas commonly metastasize to lungs, with a smaller likelihood of spreading to other tissues. ${ }^{1-4,6,8,24-26}$ Although tumors can occur at any age, they are more common in elder animals.

According to Sorenmo et al., 5 primary pulmonary tumors are rare in cats, which suggests that when found they may have mammary gland origin. Recent studies reveal that over $80 \%$ of mammary gland tumors in cats are malignant with a rapid progression and metastasizes at early stages. ${ }^{27}$ Earlier results show that mammary metastases occur in 50-90\% of cases, with lymph nodes (83\%), lungs (83\%), pleura (22\%), and liver (25\%) being the most affected organs. ${ }^{8}$ Although we could not update the aforementioned data, De Campos et al. analyzed 37 queens and found that $35.13 \%$ of metastasis from mammary gland tumors were in regional lymph nodes. Additionally, metastases occur in all the epidermoid carcinomas, in $90 \%$ of anaplastic carcinomas, and 50\% of the adenocarcinomas. ${ }^{28}$ Moreover, the ratio for thoracic metastases in malignant tumors is $15.9 \% .{ }^{29}$ The limitation of conventional radiologic methods is the late identification of metastases, which results in less effective treatment and leads to a dim prognosis. Accordingly, chest radiographs are only able to detect pulmonary nodules larger than $4-5 \mathrm{~mm}$, and their sensitivity to detect pulmonary metastases is estimated at 65 to $97 \%$ if held at least in two projections (right lateral and ventrodorsal/dorsoventral). However, this technique increases its reliability when performed in three projections (left and right side and ventrodorsal/dorsoventral). 7,20,31

The cat in this study was referred to our hospital with only two X-ray projections performed two months before. Consequently, the scintigraphy results could not be compared with the $\mathrm{X}$-ray findings.

Scintigraphy is widely used in horses, dogs and cats. Usually, osteosarcomas and lymphomas are staged in dogs with Technetium-labeled scintigraphy. Nonethe-

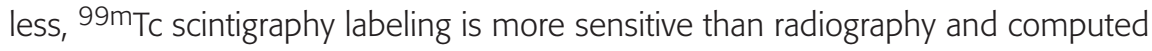
tomography for skeletal imaging, and metastatic neoplasia. 32,33 Moreover, scintigraphy is applied to assess thyroid dysfunctions, ${ }^{34}$ renal perfusion, ${ }^{35}$ portosystemic shunts, ${ }^{23}$ and gastric emptying time experiments ${ }^{36}$ in cats. In our study, thymine was labeled with $99 \mathrm{~m} \mathrm{Tc}$, proving to be effective for the detection of primary tumors and metastases. ${ }^{32,37}$

In light of our results, we suggest the expansion of scintigraphy use for metastatic lesion evaluation in the thoracic and abdominal cavities due to its sensitivity to early neoplasia stage detection when compared against other available imaging methods. One additional advantage of the scintigraphy is that it exempts particular incidences to acquire images when compared to $X$-ray examination that demands at least three projections (right-lateral, left-lateral, ventrodorsal or dorsoventral) for an adequate sensitivity. ${ }^{38}$ Moreover, the whole body can be studied with a single $99 \mathrm{~m}$ Tc-thymine dose. In this study, we detected metastases in the right kidney that was utterly unexpected. We believe that scintigraphy has been underused in veter- 


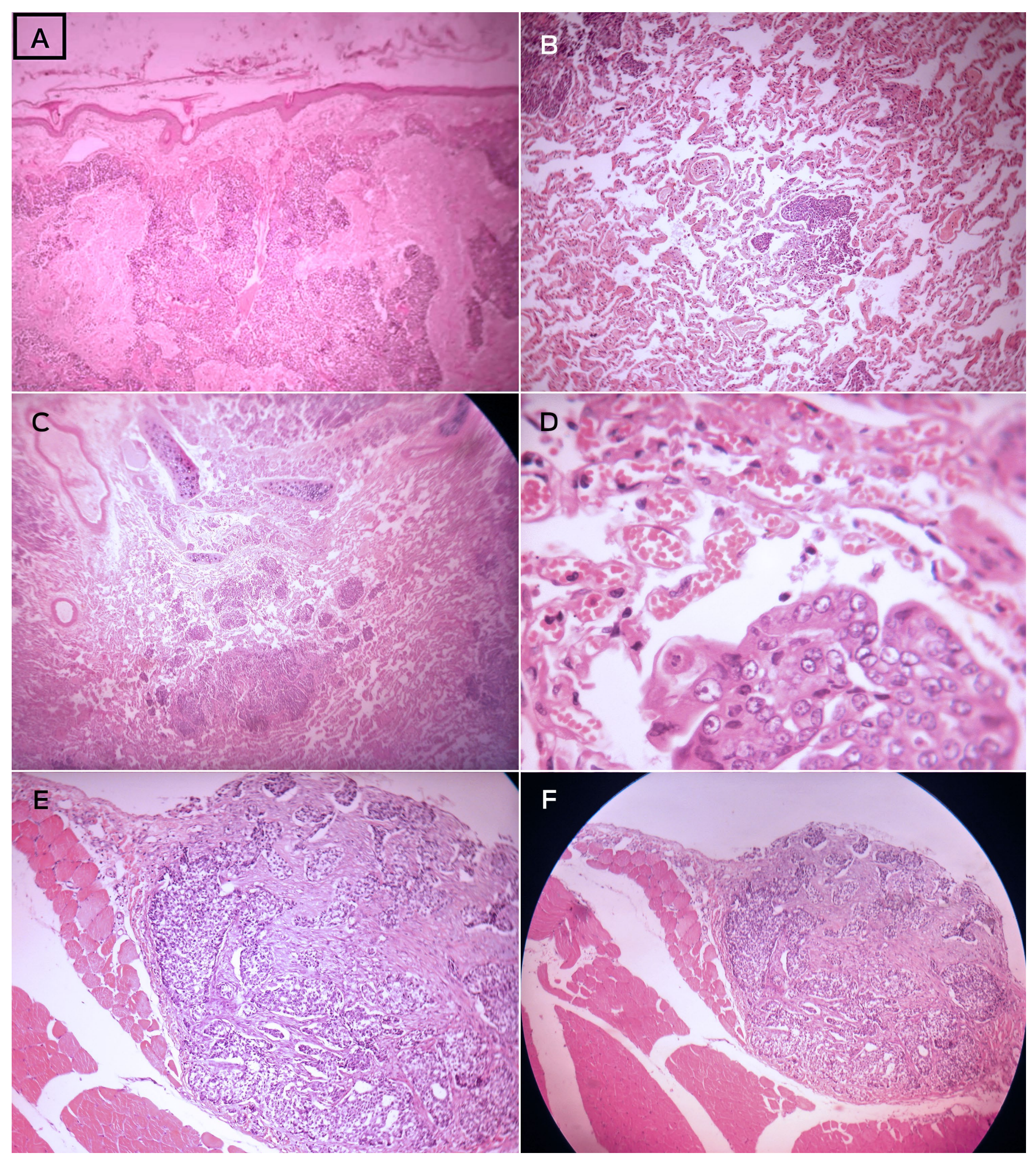

Figure 2. Histological images of feline mammary adenocarcinoma stained with hematoxylin-eosin (HE). 2A) Dermis invasion with focal points of tumoral necrosis $(201 \times 151 \mathrm{~mm})$. 2B) Pulmonary metastases of a feline mammary adenocarcinoma (100x, zoom 2,0-201 × 151 mm). 2C-D) Right kidney adenocarcinoma metastases (20x and 40x, respectively). 2E-F) magnification of $10 \times$ and $4 \times$, respectively. 
inary care, especially in feline cancer imaging and treatment, as its primary use is for thyroid disease diagnosis. 33

Traditional imaging methods are not able to detect secondary neoplasms due to their lack of sensitivity. However, scintigraphy is not a substitute for histopathologic examination on the determination of cancer stage, even if it can be an essential tool for choosing appropriate therapy and establishing prognosis.

\section{Conclusion}

In our study, the necropsy and histopathological findings were well correlated to $99 \mathrm{~m}$ Tc-THY results, both in the thoracic and abdominal cavities, especially since an otherwise undetected metastasis in the right kidney was found. Therefore, scintigraphy can be an adequate, reliable, non-invasive method to identify metastasis in feline patients with mammary adenocarcinoma. A limitation of this study is that no concomitant ultrasound or radiographic examinations were performed for comparison between techniques. Nonetheless, necropsy and histopathology validated the scintigraphy observations. 


\section{Conflicts of interest}

There were no conflicts of interest.

\section{Author contributions}

P. S. C.-B. and . S.: collection and/or assembly of data, data analysis and interpretation, and provision of patient monitoring; G. G.-S. and G. G.-S.: collection and/or assembly of data, and design; S. A. L. S. and B. G.: conception, design, and imaging analysis and interpretation.

\section{References}

1. Furian M, Sandei CFCS, Rocha E J N, Lot RFE. Estudo retrospectivo dos tumores mamários em caninos e felinos atendidos no hospital veterinário da famed entre 2003 a 2007. Rev Cient Eletrônica Med Vet. 2007;4(8):1-4.

2. Daleck CR, Franceschini PH, Alessi AC, Santana AE, Martins MIM. Aspectos clínico e cirúrgico do tumor mamário canino. Cienc Rural. 1998;28:95-100.

3. Johnston SD. Reproductive systems. In: Slatter D, editor. Textbook of small animal surgery. 2nd ed. Philadelphia: Saunders; 1993. p. 2177-99.

4. Morrisson WB. Canine and feline mammary tumors. In: Morrisson WB, editor. Cancer in dogs and cats - Medical and surgical management. Baltimore: Williams \& Wilkins; 1998. p. 591-8.

5. dos Santos PCG, Coppieters CC, Barbeiro DAF, Barcelos F. Adenocarcinoma mamário em felinos. Rev Cient Eletrônica Med Vet. 2004;3.

6. Sorenmo KU, Worley DR, Goldschmidt MH. Tumors of the mammary gland. In: Withrow SJ, Macewen EG, editors. Small animal clinical oncology. 5th ed. Philadelphia: Saunders; 2012. p. 538-52.

7. Carothers M. Neoplasia respiratória. In: Bichard SJ, Sherding RG, editors. Clínica de pequenos animais. São Paulo: Roca; 1998. p. 663-5.

8. Morris J. Mammary tumours in the cat: Size matters, so early intervention saves lives. JFMS. 2013;15:391-400

9. Giménez F. Early detection; aggressive therapy: Optimizing the management of feline mammary masses. JFMS. 2010;12:214-24

10. Gemignani F, Mayhew PD, Giuffrida MA, Palaigos J, Runge JJ, Holt DE, et al. Association of surgical approach with complication rate, progression-free survival time, and disease-specific survival time in cats with mammary adenocarcinoma: 107 cases (1991-2014). J Am Vet Med Assoc. 2018;252(11):1393-402.

11. Mattoon JS, Bryan JN. The future of imaging in veterinary oncology: Learning from human medicine. Vet J. 2013;197(3):541-52.

12. Thrift E, Greenwell C, Turner AL, Harvey AM, Maher D, Malik R. Metastatic pulmonary carcinomas in cats ('feline lung-digit syndrome'): further variations on a theme. JFMS Open Rep. 2017;3(1).

13. Aarsvold S, Reetz JA, Reichle JK, Jones ID, Lamb CR, Evola MG, et al. Computed tomographic findings in 57 cats with primary pulmonary neoplasia. Vet Radiol Ultrasound. 2015;56(3):272-7.

14. Freeman LM. Freeman and Johnson's Clinical radionuclide imaging. Orlando, FL: Grune and Stratton; 1986. 1528p.

15. Early P, Sodee B. Principles and practice of nuclear medicine. St Louis, MO: Mosby; 1995. 
16. Menezes ME, Das SK, Minn I, Emdad L, Wang XY, Sarkar D, et al. Detecting tumor metastases: The road to therapy starts here. Adv Cancer Res. 2016;132:1-44.

17. Gutfilen B, Rodrigues E, Soraggi R, Barbosa Da Fonseca LH. Preliminary observation of 99mTc-thymine imaging in breast neoplasms. Nucl Med Commun. 2001;22(10):1133-7.

18. Gutfilen B, Fonseca LM. Comparison of Tc-99m THY and Tc-99m MIBI scans for diagnosis of breast lesions. J Exp Clin Cancer Res. 2001;20:385-91.

19. Ribeiro MP, Souza SA, Lopes FP, Rosado-de-Castro PH, Fonseca LM, Gutfilen B. 99mTc-thymine scintigraphy may be a promising method in the diagnosis of breast cancer. Clinics (Sao Paulo). 2013;68(3):283-9.

20. Tanigawa N, Morimoto H, Dohmae N, Shimomatsuya T, Takahashi D, Muraoka R. In vitro growth ability and chemosensitivity of gastric and colorectal cancer cells assessed with the human tumor clonogenic assay and thymidine incorporation assay. Eur J Cancer. 1992;28:31-4.

21. León E, Rey A, Savio E, López J, Kremer E, León A. 99mTc-ADP: agente potencial para la deteccion in vivo de tumores. Rev Esp Med Nuclear. 1993;12:266.

22. Plotnik DA, Wu S, Linn GR, Yip FCT, Comandante NL, Krohn KA, et al. In vitro analysis of transport and metabolism of 4'-thiothymidine in human tumor cells. Nucl Med Biol. 2015;42(5):470-4.

23. Vandermeulen E, Combes A, de Rooster H, Polis I, de Spiegeleer B, Saunders J, et al. Transplenic portal scintigraphy using 99mTc-pertechnetate for the diagnosis of portosystemic shunts in cats: a retrospective review of 12 patients. JFMS. 2013;15(12):1123-31.

24. Pereira CT, Luiz Navarro Marques F, Williams J, Wlademir De Martin B, Primo Bombonato P. ${ }^{99 m}$ Tc-labeled dextran for mammary lymphoscintigraphy in dogs. Vet Radiol Ultrasound. 2008;49(5):487-91.

25. Hayden DW, Nielsen SW. Feline mammary tumours. J Small Anim Practice. 1971;12: 687-98.

26. Hanh KA, Adams WH. Feline mammary neoplasia: Biological behavior, diagnosis, and treatment alternatives. Feline Oact. 1997;24:5-11.

27. Hassan BB, Elshafae SM, Supsavhad W, Simmons JK, Dirksen WP, Sokkar SM, et al. Feline mammary cancer. Vet Pathol. 2017 Jan;54(1):32-43. doi: 10.1177/0300985816650243. Epub 2016 Jul 11. PMID: 27281014; PMCID: PMC7212821.

28. Couto CG, Hammer AS. Oncology. In: Sherding RG, editor. The cat diseases and clinical management. 2nd ed. Philadelphia: Saunders; 1994. p. 755-62.

29. de Oliveira LO, Rosemari de Oliveira T, Loretti AP, Rodrigues R, Driemeier D. Aspectos epidemiológicos da neoplasia mamária canina. Acta Scientiae Veterinariae. 2003;31(2):105-10.

30. Lamb CR. The canine and feline lung. In: Thrall DE, editor. Text book of veterinary diagnostic radiology. 4th ed. Philadelphia: Saunders; 2002. p. 431-47.

31. Morris JS, Nixon C, Bruck A, Nasir L, Morgan IM, Philbey AW. Immunohistochemical expression of TopBP1 in feline mammary neoplasia in relation to histological grade, Ki67, ERAlpha and p53. Vet J. 2008;175:218-26.

32. Castelo-Branco PSM, de Souza SAL, Lopes FPPL, Castro V, Sena P, Pereira JB, et al. Uso da 99mTc-timina na identificação de metástases de tumor venéreo transmissível canino com apresentação cutânea. Pesq Vet Bras. 2008;28(8):367-70. 
33. Axiak-Bechtel SM, Maitz CA, Selting KA, Bryan JN. Preclinical imaging and treatment of cancer: the use of animal models beyond rodents. Q J Nucl Med Mol Imaging. 2015;59(3):303-16.

34. Peterson ME, Castellano CA, Rishniw M. Evaluation of body weight, body condition, and muscle condition in cats with hyperthyroidism. J Vet Intern Med. 2016;30(6):1780-9.

35. Stock E, Vanderperren K, Bosmans T, Dobbeleir A, Duchateau L, Hesta M, et al. Evaluation of feline renal perfusion with contrast-enhanced ultrasonography and scintigraphy. PLoS One. 2016;11(10):e0164488.

36. Schmitz S, Götte B, Borsch C, Kunz C, Failing K, Neiger R. Direct comparison of solid-phase gastric emptying times assessed by means of a carbon isotope-labeled sodium acetate breath test and technetium Tc-99m albumin colloid radioscintigraphy in healthy cats. Am J Vet Res. 2014;75(7):648-52.

37. Castelo-Branco PSM, Motta-Silva D, Tancredi MGF, Nazério GCS, Gutfilen B, Fonseca LMB. Uso da cintilografia com 99mtc-Timina na avaliação de mesotelioma em cão: relato de caso. Rev de Ci da Vida. 2006;26 Suppl:391-2.

38. Baez JL, Sorenmo KU. Pulmonary and bronchial neoplasia. In: King LG, editor. Respiratory disease in dogs and cats. St Louis, MO: Saunders; 2002. p. 508-15. 